simplicity, and human equality. I came to know her best when we were both part of a 14-member, mainly Quaker, team that made a fact-finding trip to Israel and Palestine in 2002 and then produced a book-length report, which was published by the American Friends Service Committee in 2004 under the title When the Rain Retums: Toward Justice and Reconciliation in Palestine and Israel. As we traveled together in Israd, Palestine, and neighboring countries, she introduced us to many of the friends she had made there over the years and spent long days explaining the intricacies of the Israeli-Palestinian encounter to group members seeing it for the first time. Later, she made numerous contributions to the book as it evolved, and she also served as an anchor of loving calm for our whole, 14person collaborative writing process.

Misty lived the last eleven years of her life with cancer. When our Quaker group started its work she had just learned that her original breast cancer had metastasized in a severe way. She responded with complete honesty and a renewed determination to live as fully and as long as she could. At the end of 2005, after learning about the appearance of new, worse tumors, she and Phil Schrodt went to a conference on nonviolence in Bethlehem; they also braved the Israeli checkpoints to visit Ramallah and Gaza. She returned to Kansas and taught for just about all the spring semester.

Misty is survived by her spouse, Phil Schrodt and her parents, Henry and Dorothy Gerner. She left behind a substantial legacy in the results of her scholarship, her teaching, her institution-building, and her peace activism. But she also enriched all who knew her personally through the way she so shared her luminous gifts of friendship, wonder, and spirituality. Contributions in her memory may be made to the 'Ad Mundum' Fund that she established to help support study-abroad programs at Earlham College.

Helena Cobban

The Cbristian Science Monitor

\title{
Omeljan Pritsak (1919-2006)
}

Omeljan Pritsak, an eminent Altaicist and Turkologist, as well as founder of the Ukrainian Research Institute at Harvard, died 29 May 2006. Omeljan was born April 7, 1919 in Luka, Ukraine, and from an early age was attracted to the steppes of Central Eurasia. He studied with the Orientalist Krimsky at Kiev, but was drafted into the Soviet army. Captured by the Germans, because of his anti-Soviet sentiments and the friendship of Krimsky with Richard Hartmann in Berlin, he was able to avoid imprisonment. I first met Omeljan in 1951 in the office of H.H. Schaeder in Göttingen, where Omeljan received his degree. Schaeder praised him highly for having fruitful ideas. His first work was on the Kharakhanid dynasty of Central Asia where he entangled the difficult history of this dynasty. He continued to work on Altaic subjects and his articles in Studies in Medieval European History (Variorum, 1981) are the best collection of his work on the subject. He also published an intereting text on Khazarian-Hebrew documents of the $10^{\text {th }}$ century and also the Pechenegs (1977). But his main work was on the Origin of the Rus (Cambridge, 1981), and he was working on a second volume at his death. In it he showed the intense trading activities of the Varangians and the wide spread vista of their activities. He also had many titles in Ukrainian. 
After establishing the Ukrainian Research Institute in 1967, he worked hard on its development, and after his retirement he became the first foreign Academician of the Ukrainian Academy in Kiev. He spent time there on building a center of Oriental Studies at the University. Because of medical problems, however, he had to return to the US.

Many students, both at Harvard and Kiev, became loyal followers, and it may be said that he introduced many to Ukrainian and Altaic, including Turkish, problems. He was widely read and a kind of renaissance man. As a dear friend, his leaving us is a great loss to the field.

Richard Frye Harvard University 